\title{
THE ROAD TO UNIFORMITY IN REAL ESTATE TAXATION: VALUATION AND APPEAL
}

\section{INTRODUCTION}

The property tax, long a principal source of state revenue, remains a bulwark of local government finance. ${ }^{1}$ Recent studies indicate that nearly half of all monies raised by local governments are derived from real estate taxes. ${ }^{2}$ As the costs assumed by local governments rise, ${ }^{3}$ and as property tax rates are increased to supply the needed revenue, attention properly focuses on the procedures employed in assessing property, and the uniformity of the resulting taxation scheme. ${ }^{4}$

With only minor variations, the structure of the real estate tax systems in all states is similar. ${ }^{5}$ The local assessor in each taxing district ${ }^{6}$ appraises all real property-land and fixed improvements. ${ }^{7}$ Tax rates $^{8}$ are then set at a level which will generate the needed revenue. Shortly thereafter, the tax rolls ${ }^{9}$ are

${ }^{1}$ Cf. Comment, Equality in Taxation-Houston's Constitutional Dilemma, 10 Hous. L. Rev. 656, 657 (1973).

2 Joint Economic Comm. of Congress of the United States, 90th Cong., 2D Sess., Impact of the Property Tax-Its Economic Implications for Urban ProbLEms 6 (Joint Comm. Print 1968); Welch, The Way We Were: Four Decades of Change in the Property Tax, in Advisory Comm'n on Intergovernmental Relations, The Property Tax in a Changing Environment 29 (1974) [hereinafter cited as Changing ENvironment]; Comment, supra note 1 , at 657.

3See C. Schultze, E. Fried, A. Rivlin \& N. Teeters, Setting National Priorities, The 1973 Budget 291-305 (1972).

4 See generally J. Keith, Property Tax Assessment Practices 201-04 (1966).

${ }^{5}$ See generally Changing Environment, supta note 2.

${ }^{6}$ A major change in the past fifteen years has been the emergence of the county as the principal assessment and taxation district. See, e.g., Glidden Co. v. County of Alameda, 5 Cal. App. 3d 371, 85 Cal. Rptr. 88 (1970); Deitch Co. v. Board of Property Assessment, $417 \mathrm{~Pa} .213,209$ A.2d 397 (1965). A notable exception to the trend is Ohio, which has adopted a statewide unit for purposes of tax uniformity. See, e.g., State ex rel. Park Inv. Co. v. Board of Tax Appeals, 16 Ohio St. 2d 85, 88, 242 N.E.2d 887, 889 (1968) (per curiam).

${ }^{7}$ See, e.g., Mass. Gen. Laws ANN. ch. 59, $\$ 3$ (1973) ("Real estate for the purpose of taxation shall include all land within the commonwealth and all buildings and other things erected thereon or affixed thereto.").

${ }^{8}$ Tax rates are commonly expressed as $\$ X$ for every $\$ 100$ of assessed value, otherwise known as "millages." Assessed value is the value of the real estate as set by the local assessor. See, e.g., Philadelphia, PA., Code $\$ 19-1301$ (1974) $(\$ 1.975$ per $\$ 100$ assessed value).

${ }^{9}$ Tax rolls are records kept by the assessor which contain the assessed value and the tax liability of all real property within the taxing district. See J. KEITH, supra note 4, at 278-83. 
made public by the local assessor or assessment board; ${ }^{10}$ a taxpayer who disputes the assessment of his property may seek relief from the assessor or, if necessary, from the local appeals board. Many jurisdictions have also established statewide appeals boards which review the determinations of the local appeals boards. ${ }^{11}$ After exhausting available administrative remedies, ${ }^{12}$ the taxpayer may seek judicial review of the assessment. ${ }^{13}$

Although the real estate tax assessment systems of ten or twenty years ago ${ }^{14}$ might justly have been termed an "Augean stable,"15 during the last twenty years, many states have made herculean efforts to conform their procedures to legal requirements, contained principally in state constitutions and statutes. ${ }^{16}$ This Comment will review some of the recent attempts to remedy old problems, and will examine the nature and effectiveness of administrative and judicial remedies, in light of the goal of a fair and uniform tax system. This Comment will focus on several states with high concentrations of developed real estate: California, Connecticut, Massachusetts, New Jersey, New York, Ohio, and Pennsylvania.

\section{Changes in the System}

The typical real estate tax assessment system of twenty years ago fell short of federal and state legal requirements for several reasons. ${ }^{17}$ Local assessors were often political appointees lacking experience in the valuation of property. ${ }^{18}$ Instances of corruption were not unknown. ${ }^{19}$ Assessors in densely populated areas

${ }^{10}$ See, e.g., PA. Stat. Ann. tit. 72, § 5020-508 to -510 (1968).

${ }^{11}$ See, e.g., Conn. Gen. Stat. Ann. § 12-111 (1972); Mass. Gen. Laws. Ann. ch. $58 \mathrm{~A}, \S 1$ (1973).

${ }^{12}$ See note 201 infra \& accompanying text.

${ }^{13}$ See text accompanying notes 201-18 infra.

14 See generally Changing Environment, supra note 2; Carr, Protest, Appeal, and Judicial Review-Property Assessments, 39 CAL. S.B.J. 877, 885, 890-91, 893 (1964); Hellerstein, Judicial Review of Property Tax Assessments, 14 TAx L. REv. 327 (1959); Note, Inequality in Property Tax Assessments: New Cures for an Old Ill, 75 HaRv. L. REv. 1374 (1962).

15 One of the twelve labors that Herakles (Hercules) was ordered to perform was the cleaning of King Augeas's stables. Although the stables had been fouled for thirty years by 3,000 cattle, Herakles diverted two rivers and accomplished the task in a single day. M. Grant \& J. Hazel, Who's Who in Classical Mythology 219 (1973); C. Kerenyi, The Heroes of the Greeks 151-53 (1959).

${ }^{16}$ See text accompanying notes 31-58 infra.

${ }^{17}$ See generally, Carr, supra note 14, at 878-79; Hellerstein, supra note 14; Note, supra note 14 , at $1377-80$.

${ }^{18}$ See G. Benson, S. Benson, H. McClelland \& P. Thomson, The american Property Tax: Its History, Administration, ANd Economic Impact 3 (1965) [hereinafter cited as BENSON]; Welch, supra note 2, at 30-32.

${ }^{19}$ See, e.g., Bauer-Schweitzer Malting Co. v. City \& County of San Francisco, 8 Cal. 
were often unable to keep assessments current with fluctuating property values. ${ }^{20}$ As a result, comparable properties were assessed, and therefore taxed, at different percentages of actual value, ${ }^{21}$ in violation of the uniformity requirements of federal and state law, and the full value assessment requirements of state law. Where litigants were able to persuade a court to order compliance with these requirements, however, the legislature often responded by changing the requirements so as to validate existing practices. Legislative efforts to increase the uniformity of the system have consisted primarily of facilitating taxpayer appeals, particularly by providing access to data compiled by assessors. ${ }^{22}$

\section{A. Bases for Taxpayer Challenges}

\section{Federal Constitutional Requirements}

The equal protection clause of the fourteenth amendment to the United States Constitution requires that all property within a given class be taxed equally. ${ }^{23}$ In considering the constitutionality of a tax, courts examine the taxation scheme as applied to the individual taxpayer's property. ${ }^{24}$ Although this rule appears to provide sufficient protection to property owners, the Supreme Court has limited the fourteenth amendment's protection to cases in which there has been "intentional" and "systematic" discrimination in the assessment of the taxpayer's property. ${ }^{25}$ It has not sufficed for a taxpayer to prove merely that a mistake, incidental to the system, was made in the

3d 942, 506 P.2d 1019, 106 Cal. Rptr. 643 (1973) (indicating that an assessor had been charged with criminal misconduct). For a discussion of the impact of Bauer-Schweitzer, see Buckley, The Bauer-Schweitzer Case: Expanding the Power to Lezy Escape Assessments, 49 L.A.B. BuLL. 464 (1974).

${ }^{20}$ Comment, supra note 1 , at 661 . The problem is that properties within the district will fluctuate differently; therefore, the retention of "old" assessed values will cause inequality. If property values fluctuated at a uniform proportional rate, the currency of the assessments would be irrelevant.

21 Despite some variation in phrasing, all states base property taxation on market value. See notes 99-105 infra \& accompanying text; Benson, supra note 18 , at 3.

${ }^{22}$ See notes 80-84 \& accompanying text infra.

${ }^{23} \mathrm{See}$ Township of Hillsborough v. Cromwell, 326 U.S. 620, 623 (1946); Cumberland Coal Co. v. Board of Revision of Tax Assessments, 284 U.S. 23, 28-29 (1931); Sunday Lake Iron Co. v. Township of Wakefield, 247 U.S. 350, 352-53 (1918); $c f$. Raymond v. Chicago Union Traction Co., 207 U.S. 20, 38 (1907).

${ }^{24}$ See American Oil Co. v. Neill, 380 U.S. 451, 455 (1965); Comment, supra note 1, at 663-64.

${ }^{25}$ See Cumberland Coal Co. v. Board of Revision of Tax Assessments, 284 U.S. 23, 28-29 (1931); Sioux City Bridge Co. v. Dakota County, 260 U.S. 441, 445 (1923); Sunday Lake Iron Co. v. Township of Wakefield, 247 U.S. 350, 352-53 (1918). 
assessment: ${ }^{26}$ exact uniformity and equality are not constitutional requirements. ${ }^{27}$ More importantly, the Supreme Court has recognized the state's right to classify property for purposes of taxation; ${ }^{28}$ a classification will be upheld if it has a rational basis. ${ }^{29}$ The ability to classify enables the state to tax some types of real property more heavily than others, thereby frustrating the policy of equality. ${ }^{30}$

\section{State Constitutions and Statutes}

Given the limited scope of fourteenth amendment protection, and the difficult burden of proving "intentional" and "systematic" discrimination, taxpayers turned to state law. Most state constitutions required either "uniformity" 11 or "proportional[ity]"32 in the taxation of all property within a class; this requirement could not be met simply by the avoidance of intentional discrimination. ${ }^{33}$ In addition, many courts held that real property was a single class and that all types, such as residential, industrial, and commercial, must be treated equally. ${ }^{34}$ When

${ }^{26}$ Charleston Fed. Sav. \& Loan Ass'n v. Alderson, 324 U.S. 182 (1945); Chicago Great W. Ry. v. Kendall, 266 U.S. 94, 98-99 (1924) (dictum); Sunday Lake Iron Co. v. Township of Wakefield, 247 U.S. 350, 353 (1918).

${ }^{27}$ Allied Stores of Ohio, Inc. v. Bowers, 358 U.S. 522 (1959); Welch v. Henry, 305 U.S. I34 (1938); Lawrence v. State Tax Comm'n, 286 U.S. 276 (1932).

${ }^{28}$ Nashville, C. \& St. L. Ry. v. Browning, 310 U.S. 362 (1940); Alward v. Johnson, 282 U.S. 509 (1931); Comment, supra note 1, at 659. See also Lehnhausen v. Lake Shore Auto Parts Co., 410 U.S. 356, 359-60 (1973); Allied Stores of Ohio, Inc. v. Bowers, 358 U.S. 522, 526-27 (1959).

${ }^{29}$ New York Rapid Transit Corp. v. City of New York, 303 U.S. 573 (1938).

${ }^{30}$ Equality is satisfied for federal constitutional purposes if there is no "intentional" and "systematic" discrimination either in the assessment or taxation of real property. See notes 25-29 supra \& accompanying text; cf. Stebbins v. Riley, 268 U.S. 137, 141-42 (1925). Equality under state law has evolved into a requirement of equal taxation as an end result. See notes 31-58 infra \& accompanying text.

${ }^{31}$ E.g., PA. Const. art. 8, § 1.

${ }^{32}$ E.g., Mass. Const. pt. 2, ch. 1, § 1, art. 4.

${ }^{33}$ See, e.g., Hutensky v. Town of Avon, 163 Conn. 433, 311 A.2d 92 (1972); Shoppers' World, Inc. v. Board of Assessors, 348 Mass. 366, 203 N.E.2d 811 (1965); Ed Guth Realty, Inc. v. Gingold, 41 App. Div. 2d 479, 344 N.Y.S.2d 270, aff'd, 34 N.Y.2d 440, 315 N.E.2d 441, 358 N.Y.S.2d 367 (1973); McKnight Shopping Center, Inc. v. Board of Property Assessment, 417 Pa. 234, 209 A.2d 389 (1965). In some states, however, the burden is met by merely proving that the assessor used accepted methods of valuation. See notes 203-05 infra \& accompanying text.

${ }^{34}$ See, e.g., E. Ingraham Co. v. Town \& City of Bristol, 144 Conn. 374, 132 A.2d 563 (1957), cert. denied, 361 U.S. 929 (1960); Bettigole v. Assessors of Springfield, 343 Mass. 223, 178 N.E.2d 10 (1961); In re Appeals of Kents, Inc., 34 N.J. 21, 166 A.2d 763 (1961); State ex rel. Park Inv. Co. v. Board of Tax Appeals, 175 Ohio St. 410, 195 N.E.2d 908 (1964), cert. denied, 379 U.S. 818 (1966); Bohl Foundation v. Board of Property Assessment, 407 Pa. 567, 180 A.2d 900 (1962); $c f$. Idaho Tel. Co. v. Baird, 91 Idaho 425, 423 P.2d 337 (1967). 
taxpayers challenged the inequality of many state systems, the basis for attack was that assessment procedures violated these state constitutional mandates. ${ }^{35}$

\section{B. Taxpayers Challenge the System}

\section{Switz v. Township of Middletown}

The seminal case of a full-scale attack on the validity of real estate tax systems was Switz $v$. Township of Middletown. ${ }^{36}$ The plaintiff in Switz sought a writ of mandamus ordering the local assessor to comply with state statutes requiring "true value" assessment $^{37}$ and the equalization of all assessments within the county. ${ }^{38}$ In New Jersey, as in many jurisdictions, local assessors commonly ignored the statutory mandate to assess each parcel of real property at one hundred percent of market value. ${ }^{39}$ The result was a system in which properties in the same class were assessed at different percentages of market value, and the percentages were so widely divergent that no percentage could be termed a common level of assessment. ${ }^{40}$ To compound the problem, taxpayers were unable to discover this practice since they lacked access to assessment records. The New Jersey statute required one-hundred-percent assessment and therefore taxpayers assessed at ninety percent may have believed that they had been underassessed. In fact, the average percentage within the taxing district was about fifty percent. ${ }^{41}$ The court in Switz recognized the inherent unfairness of "secret" fractional assessment, ${ }^{42}$ and granted a writ ordering the assessor to conform to the legal requirement of full value assessment.

${ }^{35}$ See generally Carr, supra note 14.

${ }^{36} 23$ N.J. 580,130 A.2d 15 (1957). For a thorough discussion of the New Jersey real estate tax assessment system, including consideration of the historic importance of Switz, see Comment, County Tax Equalization and the Page 8 Formula: Fairmess the Hard Way, 4 Seton Hall L. Rev. 576 (1973).

${ }^{37}$ N.J. Stat. ANN. \& 54:4-2.25-.26 (1960).

${ }^{38}$ See Hammond, Real Property Tax Assessment: A Look at its Administration Practices and Procedures, 38 Albany L. Rev. 498, 514 (1974).

${ }^{39}$ Two reasons for this state of affairs were the inability of assessors to keep assessed values current, see note 20 supra \& accompanying text, and the mistaken belief that assessors were permitted to assess different types of property at different percentages of market value, see note 34 supra \& accompanying text.

${ }^{40}$ See Note, supra note 14 , at 1378.

${ }^{41}$ This may well have been the result of failure to keep valuations current with market values, rather than willful misfeasance.

${ }^{42}$ See text accompanying notes 59-61 infra. It was this secrecy that led many authorities to support the full-value assessment requirement. See, e.g., Carr, supra note 14, at 885 . 


\section{Cases After Switz}

The Switz case had a major impact in a number of other jurisdictions. In Massachusetts the real estate tax assessment system was successfully attacked on state constitutional and statutory grounds in Bettigole v. Assessors of Springfield. ${ }^{43}$ The Supreme Judicial Court of Massachusetts held that proposed assessments based upon widely differing percentages of "fair cash value"44 for different classes of real property violated state law. ${ }^{45} \mathrm{Al}$ though it recognized that a tax system could not be expected to achieve exact equality or proportionality, the Bettigole court concluded that the assessors had disregarded the constitutional and statutory requirements of full value assessment. An injunction, rather than a reduction of the individual assessments, ${ }^{46}$ was required in order to curtail the illegal practices. ${ }^{47}$

No set of cases better exemplifies the tortuous road to uniformity than the Park Investment Co. cases. ${ }^{48}$ The original Park case $^{49}$ was a mandamus proceeding to reduce the percentage assessments on commercial property in Cuyahoga County, Ohio to the percentage of full value that was applied to residential property. The court granted the writ and held that all real property must be assessed at a uniform percentage of actual value. ${ }^{50}$ Although full value assessment was required by statute, the court held that where fractional assessment was the practice, the percentage of full value must be relatively uniform throughout the

43343 Mass. 223, 178 N.E.2d 10 (1961).

44 Mass. Gen. Laws Ann. ch. 58, § 9 (1973).

${ }^{45}$ Mass. Const., pt. 2, ch. 1 , $\S 1$, art. 4, requires that all assessments of real property be "proportional." MASS. GEN. Laws ANN. ch. 59, \& 38 (1973) provides that the proportionality required by the state constitution is to be achieved by assessing each parcel at its fair cash value. See Note, supra note 14, at 1374. See also Stone v. City of Springfield, 341 Mass. 246, 168 N.E.2d 76 (1960); Carr v. Assessors of Springfield, 339 Mass. 89, 157 N.E.2d 880 (1959).

${ }^{46}$ See Mass. Gen. Laws Ann. ch. 59, $\$ 59$ (1973).

${ }^{47} \mathrm{Cf}$. Township of Hillsborough v. Cromwell, 326 U.S. 620 (1946) (individual abatement granted despite the availability of injunctive relief).

${ }^{48}$ State ex rel. Park Inv. Co. v. Board of Tax Appeals, 32 Ohio St. 2d 28, 289 N.E.2d 579 (1972) (per curiam); State ex rel. Park Inv. Co. v. Board of Tax Appeals, 31 Ohio St. 2d 183, 285 N.E.2d 356 (1972); State ex rel. Park Inv. Co. v. Board of Tax Appeals, 175 Ohio St. 410, 195 N.E.2d 908 (1964), cert. denied, 379 U.S. 818 (1964). For a history of the Park cases and an overview of the Ohio system, see Note, Real Property Assessment in Ohio, 30 Oнiо ST. L.J. 840 (1969).

49 State ex rel. Park Inv. Co. v. Board of Tax Appeals, 175 Ohio St. 410, 195 N.E.2d 908 (1964), cert. denied, 379 U.S. 818 (1964).

so Ohio law provides that all realty, regardless of nature or use, may be assessed and taxed only by a uniform rule based on value. OHro Const. art. 12, § 2; OHro Rev. Code ANn. \& 5713.01 (Page Supp. 1975). 
state $^{51}$ and among the various classes of real property. ${ }^{52}$

Despite its initial success, the Park Investment Company repeatedly returned to court in pursuit of an effective remedy. During the protracted litigation, the Ohio legislature effectively postponed implementation of the first Park decision. ${ }^{53}$ In 1972, Park moved to require the Board of Tax Appeals to show cause why it was not in contempt for failure to perform its duties in accordance with the writ of mandamus issued in 1965. The Supreme Court of Ohio respected the intervening statutory revision and denied the motion, thereby permitting the legislative reform package to proceed. ${ }^{54}$ Under the new law, uniform fractional assessment was required within each taxing district.

The outcome in Pennsylvania was similar. The Pennsylvania Constitution provides that all taxes shall be uniform for the same class of subjects within the territorial limits of the authority levying the tax. ${ }^{55}$ In 1965 a group of commercial-property owners challenged the Allegheny County assessment system which taxed commerical property at a higher percentage of full value than other classes of property. ${ }^{56}$ The Supreme Court of Pennsylvania held that the proper taxing district was the county and read the constitutional provision as determining that all real property was a single class entitled to uniform treatment. ${ }^{57}$ Significantly, the opinion indicated that uniform fractional assessment was an acceptable practice despite an explicit statutory requirement of full value assessment. ${ }^{58}$

51 Ohio is one of the few jurisdictions that require statewide uniformity. See note 6 supra.

${ }^{52} 175$ Ohio St. at 413,195 N.E.2d at 910.

${ }^{53}$ See Note, supra note 48 , at $847-48$.

${ }^{54}$ State ex rel. Park Inv. Co. v. Board of Tax Appeals, 34 Ohio St. 2d 28, 289 N.E.2d 579 (1972) (per curiam).

${ }^{55}$ PA. Const. art. 8, § 1. See Deitch Co. v. Board of Property Assessment, $417 \mathrm{~Pa}$. 213, 218, 209 A.2d 397, 400 (1965). See generally Blauner's, Inc. v. Philadelphia, 330 Pa. 340, 198 A. 889 (1938).

${ }^{56}$ Deitch Co. v. Board of Property Assessment, 417 Pa. 213, 209 A.2d 397 (1965); McKnight Shopping Center, Inc. v. Board of Property Assessment, $417 \mathrm{~Pa}$. 234, 209 A.2d 389 (1965); Morris v. Board of Property Assessment, 417 Pa. 192, 209 A.2d 407 (1965); Pittsburgh Miracle Mile Town \& Country Shopping Center, Inc. v. Board of Property Assessment, 417 Pa. 243, 209 A.2d 394 (1965); Appeal of Rieck Ice Cream Co., 417 Pa. 249, 209 A.2d 383 (1965). These cases were decided the same day, and all utilized a special computer study of assessments in Allegheny County to prove that inequality did in fact exist.

${ }^{57}$ Deitch Co. v. Board of Property Assessment, 417 Pa. 213, 209 A.2d 397 (1965).

${ }^{58} \mathrm{Id}$. at $217-18,209$ A.2d at $400-01$. 


\section{Legislative Reactions}

The courts in $S w i t z^{59}$ and its progeny, ${ }^{60}$ recognizing that "[c] Thaotic dispersion of assessment ratios constitutes arbitrariness and lack of rational classification ...." sought to force the reform of assessment systems. ${ }^{61}$ Widespread noncompliance with statutory mandates of full value assessment had produced severe inequalities in the effective ratio of tax paid to full market value. In an effort to achieve uniformity, some courts mandated full value assessment in the face of the general practice of fractional assessment. In short, the courts ordered the impossible; the legislatures were compelled to intervene.

\section{Fractional Assessment}

The legislative response was to legalize fractional assessment by setting either a fixed percentage of full value, ${ }^{62}$ a variable range, or an upper limit, ${ }^{63}$ or by requiring the local assessor to choose some percentage to be applied uniformly within the district. ${ }^{64}$ Under the last approach, each taxpayer was entitled to have his assessment levied according to this uniform percentage, often referred to as the common ratio. ${ }^{65}$ The effect of this revision was to conform the law of real property taxes to the existing assessment practices rather than the reverse. For example, it had been the practice of Connecticut assessors to assess at sixty percent of market value, despite a statutory requirement of onehundred-percent assessment. This practice, although declared illegal in E. Ingraham Co. v. Town and City of Bristol, ${ }^{66}$ was subse-

${ }^{59}$ Switz v. Township of Middletown, 23 N.J. 580, 130 A.2d 15 (1957).

${ }^{60}{ }^{6} e e_{;}$e.g., E. Ingraham Co. v. Town \& City of Bristol, 144 Conn. 374, 132 A.2d 563 (1957), cert. denied, 361 U.S. 929 (1960); Hellerstein v. Assessor of the Town of Islip, 37 N.Y.2d 1, 332 N.E.2d 279, 371 N.Y.S.2d 388 (1975).

${ }_{61}$ Note, supra note 14, at 1388. See In re Kents 2124 Atlantic Ave., Inc., 34 N.J. 21, 166 A.2d 763 (1961).

${ }^{62}$ For example, pursuant to regulations promulgated by the Ohio Board of Tax Appeals, property is taxed at about $40 \%$ of market value. See OHio Tax Study Commission, The State and Local Tax Structure in Ohio 52 (1967); Note, supta note 48 , at 844 .

${ }^{63}$ CAL. Rev. \& TAX Code $\S 401$ (West 1970) ("Every assessor shall assess all property subject to general property taxation .... in the county at a publicly announced ratio of his own choosing which shall be between 20 and 25 percent of full cash value."), as amended, (Supp. 1976) (25\% set ratio); OHio Rev. Code ANN. $\$ 5715.01$ (Page 1973) (50\% maximum).

${ }^{64}$ See, e.g., Deitch Co. v. Board of Property Assessments, 417 Pa. 213, 209 A.2d 397 (1965).

${ }_{65}$ See text accompanying notes $179-89$ infra.

${ }^{66} 144$ Conn. 374, 132 A.2d 563 (1957), cert. denied, 361 U.S. 929 (1960). 
quently validated by the Connecticut General Assembly. ${ }^{67}$

Commentators have disagreed over the relative merits of full value assessment and fractional assessment. ${ }^{68}$ The principal argument for full value assessment has been that the taxpayer can discover any overassessment at the time he is notified of his assessment. He need only compare the assessed value of his property with his own estimate of its market value. ${ }^{69}$ Early notice of overassessment is important should the taxpayer choose to appeal, because many jurisdictions have restrictive statutes of limitations ${ }^{70}$ which are inflexibly applied. ${ }^{71} \mathrm{~A}$ further point urged on behalf of full value assessment is that it lessens the taxpayer's problem of proof. A court or appeal board can resolve the claim of overassessment simply by ascertaining the actual market value of the property. ${ }^{72}$

This position fails to distinguish between "secret" fractional assessment ${ }^{73}$ and legislatively authorized fractional assessment. In the former case, where a statutory requirement of full value assessment is disregarded, the taxpayer cannot determine

${ }^{67}$ See Conn. Gen. Stat. Ann. \& 12-64 (1972). The New Jersey legislature enacted a similar law following the Switz case. See N.J. STAT. ANN. \$ 54:4-2.25 (1960). Several months after the New York Court of Appeals ordered compliance with the statutory requirement of full value assessment, the state legislature began consideration of a bill that would legalize fractional assessment. N.Y. Times, Mar. 10, 1976, at 30, col. 1 .

${ }^{68}$ See Changing Environment, supra note 2, at 2-13; Carr, supra note 14, at 685.

Avoiding the costs of converting to a full value assessment system where a fractional assessment system is in use may be reason to retain the latter system. If the existing system is so chaotic, however, that no "average" or "common" fractional level can be identified, then a complete reappraisal will be necessary even if fractional assessment is authorized by statute. The costs of converting may depend upon the nature of the existing fractional assessments. The intentional and systematic application of different percentages to different groups of properties could be corrected more easily than the random application of different percentages to similar properties. Conversion will be especially burdensome if the assessments have not been kept current with changes in market values. See note 20 supra \& accompanying text.

${ }^{69}$ See Hellerstein, supra note 14, at 348; Hezel, Residential Property Assessments in the City of Buffalo: A Study of the Use of Administrative Discretion, 23 BUfFalo L. REv. 411, 418 (1974).

${ }^{70}$ See, e.g., Conn. Gen. Stat. Ans. $\S \S 12-55,-112$ (1972) (no more than thirty days); N.J. Stat. ANN. \$§ 54:3-18, -21 (1960) (approximately 200 days); N.Y. REAL Prop. TAX LAW $\$ 702$ (McKinney 1972) (thirty days).

${ }^{71}$ See, e.g., Danis v. Middlesex County Bd. of Taxation, 113 N.J. Super. 6, 272 A.2d 542 (App. Div. 1971); United Artists E. Theatres, Inc. v. Board of Assessors, 76 Misc. 2d 26, 349 N.Y.S.2d 284 (1973).

${ }^{72}$ See Changing Environment, supra note 2, at 6; Hezel, supra note 69, at 419 . Market value multiplied by the common ratio equals assessed value. Where the ratio is $100 \%$, market value equals assessed value. The point is important because often the taxpayer's greatest obstacle lies in proving the existing common ratio. See Carr, supra note 14 , at 885-86.

${ }^{73}$ See text accompanying notes $36-42$ supra. 
whether he has been overassessed ${ }^{74}$ unless he knows the average percentage of market value actually applied in his district. ${ }^{75}$ On the other hand, where fractional assessment (at a fixed percentage or within an established range ${ }^{76}$ ) is authorized, the taxpayer need only multiply the market value of his property by the prescribed percentage and compare the result with the assessed value of his property. In short, the early notice value is served where the actual percentage applied by the assessor approximates the authorized percentage set out in the statute. The early notice function does not turn on the latter being set at one hundred percent. Similarly, the taxpayer's problem of proof on appeal is not significantly more difficult where fractional assessment is authorized than where full value assessment is required. As long as the court or appeal board knows the percentage actually applied ${ }^{77}$ by the assessor, it can resolve the claim of overassessment. In an appropriate case, the taxpayer is free to prove that the assessor has overstated the actual percentage in defending his assessment. ${ }^{78}$

\section{Access to Information}

Although legislative reform efforts centered on the legalization of fractional assessment, another important change was the increased availability to taxpayers of a wide range of information relevant to real estate taxation within the district. ${ }^{79}$ Probably the most comprehensive effort took place in California. In addition to legalizing fractional assessment, ${ }^{\mathbf{} 0}$ the legislature in 1966 per-

${ }^{74}$ If a property owner thinks his property is to be assessed at its full market value, as full value assessment would require, he is likely to remain silent if he believes that his property is assessed at a lower percentage. Therefore, if his property is assessed at $\mathbf{7 5 \%}$ he will not appeal. In fact, the assessor may have created a system of "secret" assessment at $60 \%$ and the hypothetical taxpayer actually has been overassessed. The problem is one of notice.

${ }^{75}$ See Welch, supra note 2, at 33.

${ }^{76}$ See notes 62-65 supra \& accompanying text.

${ }^{77}$ See, e.g,, CAL. Rev. \& TAX Code $\S 401$ (West Supp. 1976). A problem arises, in the absence of a fixed percentage, if the assessor is not required to introduce the percentage he has applied. The taxpayer then faces an impossible task in attempting to prove overassessment. See Ehrman, Administrative Appeal and Judicial Review of Property Tax Assessments in California-The New Look, 22 Hastings L.J. I, 15 (1970).

${ }^{78}$ See Sommer, A Summary of Current Real Estate Tax Assessment Protest and Judicial Review in New York State, 44 N.Y.S.B.J. 475, 480 (1972).

${ }^{79}$ See, e.g., CaL. Rev. \& TaX Code \& 1606 (West Supp. 1976); Ohio Rev. Code ANN. \$ 5715.07 (Page 1973). See generally Ehrman, supra note 77, at 15-16.

${ }^{80}$ The California legislature discovered that a fractional assessment system had evolved in California and had created significant problems. At that time the California Constitution, art. XI, $\S 12$ required that all property be assessed at "full cash value," statutorily defined as full market value, but the new law required only that assessments 
mitted the taxpayer access to much information formerly unavailable to him. This information included the percentage actually applied by assessors within their districts, ${ }^{81}$ the sales-ratio data compiled by the state board of equalization, ${ }^{82}$ the methods employed by the assessors in valuing property, ${ }^{83}$ and the assessed and market values assigned to other properties within the districts. ${ }^{84}$ Information of this type facilitates the taxpayer's efforts to secure uniform treatment, especially during the appeal process. It is to that process that this Comment will now turn.

\section{Administrative and Judicial Appeal}

Commentators have focused on administrative appeal and judicial review of real estate tax assessments as the principal means for achieving uniformity in the tax system. ${ }^{85}$ Although as a matter of due process states are not required to provide judicial review of assessments, ${ }^{86}$ due process does require some type of administrative appeal, with notice and hearing, before the assessment becomes final. ${ }^{87}$ Because the valuation of property is

be set at a fixed fraction of "full cash value." See CaL. Rev. \& TAX Code $\$ 401$ (West 1970), as amended, (Supp. 1976). The constitutionality of the measure was upheld in County of Sacramento v. Hickman, 66 Cal. 2d 841, 428 P.2d 593, 59 Cal. Rptr. 609 (1967) (en banc). See generally Red Bluff Developers v. Tehama County, 258 Cal. App. 2d 668, 66 Cal. Rptr. 229 (1968).

${ }^{81}$ Cal. Rev. \& TAX Code $\S 401$ (West 1970), as amended, (Supp. 1976). The problems faced by the taxpayer in proving that other properties are assessed at a rate lower than that applied to his own property are discussed in text accompanying notes 179-200 infra.

${ }^{82}$ CAL. Rev. \& TAX CoDE $\S \S 1815,1817-19$ (West 1970), as amended, (Supp. 1976). The nature of sales-ratio information and its potential value to the taxpayer are discussed in text accompanying notes 185-200 infra.

${ }^{83}$ Cal. Rev. \& TAX Code $\$ 1606$ (West Supp. 1976). The various methods of determining property value are discussed in text accompanying notes 98-178 infra. at 9 .

${ }^{84}$ Cal. Rev. \& TAX Code $\S 1606$ (West Supp. 1976). See Ehrman, supra note 77,

${ }^{85}$ Because appraisal is a particularly inexact science, and because assessors are often unable to keep abreast of changes within the district, the appeal process is needed to ascertain and remedy inequalities that arise from defects within the system as well as those which result from arbitrary actions of the assessor. See, e.g., Carr, supra note 14; Ehrman, supra note 77; Hellerstein, supra note 14; Hezel, supra note 69. "To the extent the initial assessment is properly made, the need to be concerned with . . . administrative appeal and judicial review is considerably less." Carr, supra note 14, at 878 .

${ }^{86}$ Hodge v. Muscatine County, 196 U.S. 276 (1905). Most jurisdictions, however, do provide for judicial review. See, e.g., Mass. Gen. Laws Ann. ch. 58A, § 13 (Supp. 1974); N.Y. Real Prop. Tax Law $\$ 700$ (McKinney 1972); Ohio Rev. Code AnN. $\$ \S 5717.04-.05$ (Page 1973).

${ }^{87}$ See Hellerstein, supra note 14, at 327. Excessive assessments are not necessarily reviewable unless they are fraudulent, arbitrary, or capricious. Jeffery Apt. Bldg. Corp. v. Harding, 347 Ill. 336, 179 N.E. 881 (1932). For a discussion of factors relevant to the 
far from an exact science, ${ }^{88}$ and because the methods used by local assessors are often not made public, ${ }^{89}$ an administrative appeal is necessary both to afford the taxpayer a remedy and to monitor the actions of the assessor..$^{90}$

\section{A. Administrative Appeal}

The initial procedure in challenging an assessment is an appeal to a local board of appeals. ${ }^{91}$ The taxpayer bears the burden of proving that the assessment is erroneous. He must produce evidence showing that the property was overassessed ${ }^{92}$ in order to overcome the presumption of validity generally accorded assessments. ${ }^{93}$ Such evidence may demonstrate either that the market value of the property was lower than that determined by the assessor, or that the assessor applied to that value a higher percentage than (1) the actual common ratio or (2) the prescribed common ratio. ${ }^{94}$ Once the taxpayer provides sufficient evidence to rebut the presumption, the assessor must introduce evidence supporting the validity of the assessment. ${ }^{95}$ The local board then determines the market value according to the evidence, and applies the proper common ratio to calculate the assessment. Similar procedures govern an appeal before a

nature of a hearing required by due process, see Friendly, Some Kind of Hearing, $123 \mathrm{U}$. PA. L. REv. 1267 (1975).

88 "As long as an assessment depends on such a subjective standard as the market value of an item of property ... there will be sharp differences of opinion between the taxpayer and the assessing authorities. What is important is that value be determined in the same manner for everyone." Ehrman, supra note 77, at 4.

${ }^{89}$ See Carr, supra note 14 , at 879.

${ }^{90}$ This is especially true in jurisdictions that have created statewide agencies, both to handle appeals from local board decisions and to oversee the proper functioning and equality of the state tax systems. See note 11 supra \& accompanying text. For example, N.Y. Real Prop. Tax Law $\S \S 1524,1526$ (McKinney 1972) creates boards of assessment review that have primary responsibility for seeing that all real property within their jurisdiction is assessed equally. See Hezel, supra note 69, at 412-14.

${ }^{91}$ See generally Ehrman, supra note 77; Hellerstein, supra note 14; Hezel, supra note 69; Sommer, supra note 78.

${ }^{92}$ E.g., Dickau v. Town of Glastonbury, 156 Conn. 437, 242 A.2d 777 (1968); Broadway-Saranac Lake Corp. v. Board of Assessors, 43 App. Div. 2d, 349 N.Y.S.2d 830 (1973); Deitch Co. v. Board of Property Assessment, 417 Pa. 213, 209 A.2d 397 (1965).

${ }^{93}$ E.g., CAL. Admin. Code tit. 18, § 8321 (a) (1969); Sommer, supra note 78, at 485.

${ }^{94}$ The market value must first be determined by appropriate valuation methods, and the resulting figure is then reduced by the assessment ratio. See County of Sacramento v. Hickman, 66 Cal. 2d 841, 848, 428 P.2d 593, 600, 59 Cal. Rptr. 609, 613 (1967) (en banc).

${ }^{95}$ See, e.g., Deitch Co. v. Board of Property Assessment, 417 Pa. 213, 221-22, 209 A.2d 397, 402 (1965); Sommer, supra note 78, at 485-86. 
statewide administrative appeals board, ${ }^{96}$ which is often permitted to set the assessed value either above or below that fixed by the local board or the assessor. ${ }^{97}$

\section{Determining Market Value}

The key to uniform assessments, and the first point raised on appeal, is the accurate valuation of the property. ${ }^{98}$ Depending on the jurisdiction, real estate is required to be assessed at "actual value,"99 "full cash value,"100 "fair cash value,"101 "full value,"102 or "true and actual value."103 All such standards have been held to require assessment at market value, ${ }^{104}$ defined as the price that the property would bring in a fair, arm's length transaction between willing parties. ${ }^{105}$

The three principal methods utilized in the valuation of real estate are the comparable-sales method, ${ }^{106}$ the capitalization-ofincome method, ${ }^{107}$ and the reproduction-cost-new-less-depreciation (RCNLD) method. ${ }^{108}$ Although each method is best suited to a particular type of property, it is generally accepted that the optimal valuation employs all three. ${ }^{109}$ For purposes of assess-

${ }^{96}$ See notes 11, 90 supra \& acccompanying text.

${ }^{97}$ See, e.g., Rek Inv. Co. v. City of Newark, 80 N.J. Super. 552, 557-58, 194 A.2d 368, 372 (App. Div. 1963).

${ }^{98}$ See KeITH, supra note 4 , at $42-43$.

${ }^{99}$ Pa. STAT. ANN. tit. 72, § 5020-402 (1972).

${ }^{100}$ Cal. Rev. \& TAX Code $\$ 401$ (West 1970), as amended, (Supp. 1976); Md. AnN. CODE art. 81, § 14 (1957).

${ }^{101}$ Ill. Rev. Stat. ch. 120, $§ 501$ (1) (1970); Mass. Gen. Laws ANn. ch. 59, $\$ 38$ (1973).

102 N.Y. Real Prop. Tax Law $\$ 306$ (McKinney 1972).

${ }^{103}$ Conn. Gen. Stat. Rev. § 12-63 (1972).

104 See, e.g., Bornstein v. State Tax Comm'n, 227 Md. 331, 337, 176 A.2d 859, 861-62 (1962); Deitch Co. v. Board of Property Assessment, 417 Pa. 213, 217, 209 A.2d 397, 400 (1965). See also KeITH, supra note 4, at 445-46.

${ }^{105}$ See, e.g., De Luz Homes Inc. v. San Diego, 45 Cal. 2d 544, 562, 290 P.2d 544, 554 (1955); Springfield Marine Bank v. Property Tax Appeal Bd., 44 Ill. 2d 428, 430, 256 N.E.2d 334, 336 (1970); First Nat'l Stores, Inc. v. Board of Assessors, 358 Mass. 554, 560, 265 N.E.2d 848, 852 (1971); Cuyahoga County Bd. of Revision v. One Euclid Co., 16 Ohio St. 2d 43, 46, 242 N.E.2d 582, 584 (Ct. App. 1968); Kargman v. Jacobs, 113 R.I. 696, 706-07, 325 A.2d 543, 549 (1974) (Joslin, J., dissenting). See CaL. Rev. \& TAX CODE $\$ 110$ (West 1970) ("the amount at which property would be taken in payment of a just debt from a solvent debtor").

${ }^{106}$ See generally Parvin, Market Approach to Value, in Encyclopedia of Real. Estate APPRAISING 85 (E. Friedman ed. 1959) [hereinafter cited as EncYCLOPEDIA].

${ }^{107}$ See generally Hollebaugh, Income Approach to Value, in EnCYcLoPEdiA, supra note 106 , at 54 .

${ }^{108}$ See generally Johnson, Cost Approach to Value in ENcyclopedia, supra note 106, at 37; Smith, Issues and Problems in the Valuation of Real Estate, N.Y.U. 30TH INST. ON FED. TAX. 209 (1972).

${ }^{109}$ All facts regarding the property being valued should be carefully considered, 
ment review, most states require that all methods be considered and provide that all such evidence is admissible. ${ }^{110}$ The most important element in selecting a method from the standpoint of uniformity is the assessor's familiarity with the method. If the assessor fails to apply properly all components of the chosen method to the subject property, the resulting valuation will not be correct and the local assessments will not be uniform.

\section{a. Comparable-Sales Method}

The comparable-sales method is recognized as the most accurate method of determining market value. ${ }^{111}$ The assessor compares the subject property with recently sold properties of a similar nature. ${ }^{112}$ The comparable-sales method is most often used with residential property, because a sufficient number of sales to provide a valid comparison can usually be found. ${ }^{113}$ Many factors are relevant in such a comparison-for example, location, size, facilities, age, income, expenses, use, and type of construction-and no single factor is controlling. ${ }^{114}$ The properties compared need not be identical, as the aim is to show their relative values by analyzing the characteristics of each, taking into consideration all uses to which the property is adapted and

and no single method of appraisal should be controlling. Federated Dep't Stores, Inc. v. Board of Tax Review, 162 Conn. 77, 86, 291 A.2d 715, 720 (1971); New Brunswick v. Division of Tax Appeals, 39 N.J. 537, 544, 189 A.2d 702, 705-06 (1963); Heiman v. Bishop, 272 N.Y. 83, 87-88, 4 N.E.2d 944, 945-46 (1936). Contra, Kargman v. Jacobs, 113 R.I. 696, 704, 325 A.2d 543, 547-48 (1974) (choice of recognized methods within the discretion of assessor).

110 See, e.g., Mass. Gen. Laws ANn. ch. 58, \& 10 (1973).

111 National Folding Box Co. v. New Haven, 146 Conn. 578, 584, 153 A.2d 420, 424 (1959). See Parvin, supra note 106, at 86; Smith, supra note 108, at 212 . Smith labels this method the "market data approach." Id. Arm's length sales of comparable property that are recent and voluntary offer reliable evidence of value because they indicate market opinion of value.

112 Previous sales of the subject property often provide the best evidence of market value. See Samuel Hird \& Sons v. Garfield, 87 N.J. Super. 65, 208 A.2d 153 (1965); Lane Bryant, Inc. v. Tax Comm'n, 21 App. Div. 2d 669, 249 N.Y.S.2d 994 (1964), aff'd, 19 N.Y.2d 715, 225 N.E.2d 882, 279 N.Y.S.2d 175 (1967); State ex rel. Park Inv. Co. v. Board of Tax Appeals, 175 Ohio St. 410, 195 N.E.2d 908 (1965), cert. denied, 379 U.S. 818 (1966). The requirements that the sale be recent and at arm's length are discussed in Smith, supra note 108, at 217, 218-19.

${ }^{113}$ See Santemma, Review of Real Estate Tax Assessments, 2 Real Estate L.J. 685, 686 (1974).

${ }^{114}$ McKnight Shopping Center v. Board of Property Assessment, 417 Pa. 234, 209 A.2d 389 (1965). The difficulty is in the determination of whether two properties are "comparable." The assessor must be able to analyze the characteristics that are important in the market place, and to determine which characteristics are present in the subject property and in the potential "comparables." See Smith, supra note 108, at 212-15. 
might be applied. ${ }^{115}$ The major problem with the comparablesales method is locating a sufficient number of recent sales of "comparables" to provide a reliable comparison. ${ }^{116}$ Where none at all is available, this method cannot be used.

\section{b. RCNLD Method}

This method, like capitalization of income,,$^{117}$ is often employed when there are few "comparable" sales, ${ }^{118}$ as in the case of "specialty" buildings that are rarely, if ever, sold. ${ }^{119}$ The RCNLD method is applied to the building, while the comparable-sales method usually can determine the market value of the land. ${ }^{120}$ The RCNLD method entails computing reproduction cost-the amount, based on current market costs for raw materials, labor, management, and capital, that would be spent to provide a duplicate building in terms of facilities, amenities, and space ${ }^{121}$-and then adjusting for depreciation (unless the building is brand-new). This method is most accurate when the building is sufficiently new to ensure that a proper depreciation factor can be calculated; ${ }^{122}$ when the building is old, valuation is difficult and therefore likely to be inaccurate.

The RCNLD method is often used as a check on the valuations produced by the other methods, rather than as the sole

115 Deitch Co. v. Board of Property Assessment, 417 Pa. 213, 223, 209 A.2d 397, 402 (1965). The selling price of an otherwise comparable property can be adjusted for differences in time and condition. For example, sales that are somewhat "old" can be adjusted to current price levels. Parvin, supra note 106.

${ }^{116}$ Four or five sales of comparable property are usually sufficient to permit accurate valuation. Smith, supra note 108, at 215 .

${ }^{117}$ See text accompanying notes 126-78 infra.

${ }^{118}$ Some types of properties are not sufficiently numerous in a particular area, nor are they sold very often. Smith, supra note 108 , at 215 .

119 Such buildings include opera houses, stock-exchange buildings, and certain office buildings. See In re Joseph E. Seagram \& Sons, Inc. v. Tax Comm'n, 18 App. Div. 2d 109, 238 N.Y.S.2d 228 (1963), aff'd 14 N.Y.2d 460, 200 N.E.2d 447, 251 N.Y.S.2d 460 (1964). In that case Seagram Company built a spectacular new office building for its corporate headquarters, and the construction costs exceeded the market value alleged by the owner. Because the office building was unusual, the comparable sales method could not be used. Also, the taxpayer's income calculation neglected the imputed income attributable to the owner-occupied parts of the premises, as well as the publicity value of the building. The court held that the construction costs represented the value of the building for tax assessment purposes at least for the tax years soon after construction. The case was noted in 29 Albany L. Rev. 158 (1965) and 63 Colum. L. REv. 1528 (1963).

120 This is sometimes referred to as the "land-residual" method.

${ }^{121}$ See KeITH, supra note 4, at 473.

${ }^{122}$ See, e.g., Joseph E. Seagram \& Sons, Inc. v. Tax Comm'n, 18 App. Div. 2d 109, 238 N.Y.S.2d 228 (1963), aff'd, 14 N.Y.2d 314,200 N.E.2d 447,251 N.Y.S.2d 460 (1964). 
approximation of value. ${ }^{123}$ It tends to set the upper limit on value, because an investor probably will not pay more for an existing building than the cost of building a substitute, even when depreciation is taken into account. ${ }^{124}$ Often, when an insufficient number of comparable sales is available, assessment boards and courts reluctant to rely on the capitalization-ofincome method ${ }^{125}$ use the RCNLD method either as a check or as the sole determinant of value.

\section{c. Capitalization of Income}

Capitalization of income is the prevailing method of determing the fair market value of commercial properties, especially apartment buildings, office buildings, and shopping centers. ${ }^{\mathbf{1 2}}$ Commercial properties are essentially investments similar to corporate bonds. The market value of any investment depends upon the stream of income it is expected to produce over its lifetime. ${ }^{127}$ Capitalization involves estimating the annual income to be generated over the life of the investment, and then applying a capitalization rate $^{128}$ to each annual amount to compute its

${ }^{123}$ See Johnson, supra note 108 , at 37-38.

124 There has been much disagreement over whether the RCNLD method sets an upper limit on value. The New York courts hold that it does. Shereff v. Tax Comm'n, 42 App. Div. 2d 593, 345 N.Y.S.2d 76 (1973); Elmhurst Towers, Inc. v. Tax Comm'n, 34 App. Div. 2d 570, 309 N.Y.S.2d 680 (1970); Federated Dep't Stores, Inc. v. Podeyn, 32 App. Div. 2d 823, 302 N.Y.S.2d 289 (1969). Other states have rejected the New York rule. Bornstein v. State Tax Comm'n, 227 Md. 331, 176 A.2d 859 (1962); Kargman v. Jacobs, 113 R.I. 696, 325 A.2d 543 (1974). Kargman's rationale is that incomeproducing property sells frequently at a price higher than reproduction cost when the property is new, well-managed, and tenanted; when the income is immediately available; and when no additional capital, risk, or delay is required to create a good investment. This appears to represent the more economically valid rule. Gifford, Should $R e-$ placement Cost Impose a Ceiling on Real Property Tax Assessment?, 26 J. TAXation 314 (1967).

125 Because capitalization of income involves computations based on estimates of income, expenses, and interest rates, it can produce widely divergent results regarding a given piece of property. The courts have urged that the method be used with care and that the results be checked against all available data. E.g., Burritt Mut. Sav. Bank v. New Britain, 146 Conn. 669, 154 A.2d 608 (1959); New Brunswick v. State Div. of Tax Appeals, 39 N.J. 537, 189 A.2d 702 (1963).

${ }^{126}$ Ancel, Determining Fair Market Value of a Shopping Center for Purposes of Property Tax Assessment, 1965 U. ILL. L.F. 253 (1965); Sommer, supra note 78, at 477-78. But of. McCrory Stores Corp. v. Asbury Park, 89 N.J. Super. 234, 214 A.2d 526 (App. Div. 1965).

${ }^{127}$ See Hollebaugh, supra note 107, at 54. See Koeppel \& Kramer, Property Tax Assessments: Contract Rent is Fair Market Rent, Or Is It? , 2 REAL. Estate L.J. 561 (1973).

${ }^{128}$ The capitalization rate is the rate of return that an investor would require to invest his capital in a particular investment. See Fisher, Capitalization Rates, 25 NAT'L TAX J. 263 (1972); text accompanying notes 161-70 infra. 
present market value. ${ }^{129}$ The present values are then added together to derive the total market value. Two questions must be addressed in applying this method: (1) How is income to be computed? and (2) At what rate is income to be capitalized?

\section{(i) Computing Income}

When estimating future income, the assessor must compute gross income (determined from actual figures or from estimates) as well as the expenses (actual or estimated) to be subtracted from gross income. The resulting net income figure represents the annual income stream actually or predictably available to the owner, and is therefore the proper figure to be analyzed in determining present value. ${ }^{130}$ Average net income over a threeto five-year period-stabilized net income-is often used in projecting future income. ${ }^{131}$

Conflict exists over whether to use actual (contract) rent or fair rental value in computing gross income. The prevailing view favors the fair rental value standard. As stated in People ex rel. 379 Madison Avenue v. Boyland: ${ }^{132}$

Assessments cannot be made to trail behind every turn in the fortunes of real property. There are times when property must bear a share of taxation proportionate to value even though it may then have no income, or an income inadequately focused to true value. There are times when the full measures of ephemeral surges of increased income should not be reflected in assessments in fairness to the owner. ${ }^{133}$

Fair rental value, rather than actual income, represents the earning capacity of the property and, according to the proponents of fair rental value, that capacity should be considered for purposes of taxation. ${ }^{134}$ Fair rental value is derived by comparing the sub-

129 Fisher, supra note 128. The present value is the amount of money that an investor would pay presently for the right to receive a particular stream of income in the future. For example, given a $\mathbf{5 \%}$ interest rate, an investor would pay $\$ 100$ presently for the right to receive $\$ 105$ in one year. See generally Weston \& Brigham, Managerial Finance 143-60 (3d ed. 1969).

${ }^{130}$ See notes 126-28 supra \& accompanying text.

${ }^{131}$ See New Brunswick v. Division of Tax Appeals, 39 N.J. 537, 189 A.2d 702 (1963); Ancel, supra note 126, at 258.

132281 App. Div. 588, 121 N.Y.S. 2d 238 (1953).

${ }^{133} I d$. at 590,121 N.Y.S.2d at 241.

${ }^{134}$ E.g., Clayton v. Los Angeles, 26 Cal. App. 3d 390, 102 Cal. Rptr. 687 (Ct. App. 1972); Burritt Mut. Sav. Bank v. New Britain, 146 Conn. 669, 154 A.2d 608 (1959); 
ject property to similar income-producing properties in the district in regard to location, size, facilities, and tenants, with the object of determining the rent that the owner should receive for his space. ${ }^{135}$

The proponents of actual income fall into two groups. A minority of the courts have held that actual income should be given great weight unless the subject property clearly is not being used for its highest and best use. ${ }^{136}$ More recent cases ${ }^{137}$ have held that actual income is the primary determinant of gross income and may be disregarded only when the assessor can establish that the contract rent is less than fair rental value. These cases recognize the importance of stability in assessed property values, ${ }^{138}$ but reasonably conclude that tenants are rarely charged inadequate rentals. Thus in Parkview Village Associates $v$. Borough of Collingswood, ${ }^{139}$ the court held that actual rental income from a large, well-managed apartment project was prima facie evidence of gross income, rebuttable only by convincing evidence to the contrary.

A problem arises in the use of actual income when commercial properties are covered by long-term leases entered into many years prior to the current assessment date and when the rentals are therefore lower than current fair rental value. ${ }^{140}$ Even the most recent decisions accepting actual rental income as

Springfield Marine Bank v. Tax Appeals Bd., 44 Ill. 428, 256 N.E.2d 234 (1970); New Brunswick v. Division of Tax Appeals, 39 N.J. 537, 189 A.2d 702 (1963).

${ }^{135}$ E.g., Parkview Village Associates v. Borough of Collingswood, 62 N.J. 21, 297 A.2d 842 (1972). Fair rental value is based on the highest and best use of the property, whether or not the property is currently so employed. E.g., Federated Dep't Stores, Inc. v. Board of Tax Review, 162 Conn. 77, 291 A.2d 715 (1971). The Federated Dep't Stores case is interesting because the court valued that portion of the land being used as a parking lot on the basis of its full department store use, although a parking lot was necessary to create the full value of the store itself.

${ }^{136}$ Somers v. City of Meriden, 119 Conn. 5, 174 A. 184 (1934); Mid-Island Shopping Plaza, Inc. v. Podeyn, 25 Misc. 2d 972, 204 N.Y.S.2d 11 (Sup. Ct. 1960), aff'd, 14 App. Div. 2d 571, 218 N.Y.S.2d 249, aff'd, 10 N.Y.2d 966, 180 N.E.2d 63, 224 N.Y.S.2d 283 (1961).

${ }^{137}$ Federated Dep't Stores, Inc. v. Board of Tax Review, 162 Conn. 77, 291 A.2d 715 (1971); Parkview Village Associates v. Borough of Collingswood, 62 N.J. 21, 297 A.2d 942 (1972); Caroldee Realty Corp. v. Board of Assessors, 73 Misc. 2d 41, 340 N.Y.S.2d 774 (Sup. Ct. 1972); F.W. Woolworth Co. v. Commission of Tax and Assessment, 26 App. Div. 2d 759, 272 N.Y.S.2d 257 (1966). (1963).

${ }^{138}$ See New Brunswick v. Division of Tax Appeals, 39 N.J. 537, 189 A.2d 702

${ }^{139} 62$ N.J. 21, 297 A.2d 842 (1972).

${ }^{140}$ In the leading case of People ex rel. Gale v. Tax Comm'n, 17 App. Div. 2d 225, 233 N.Y.S.2d 501 (1962), the court declined to use a depression lease rental as evidence of gross income. 
prima facie evidence of fair rental value ${ }^{141}$ distinguish clearly the long-term-lease situation. Their theory is that other taxpayers in the district should not be made to bear larger tax burdens because the taxpayer-owner is bound by a disadvantageous lease. Underlying this position is the view that where actual rental income is less than fair rental value, the tenant has a "bonus" lease to the extent of the difference, and its value plus the owner's actual rent equals the taxable value of the property. ${ }^{142}$

Using the fair-rental value in the long-term-lease situation, however, is difficult to reconcile with the basic theory of property valuation for tax purposes. Most of the decisions requiring the use of fair rental value purportedly base this result on the statutory standard for valuation ${ }^{143}$ but fail to recognize that market value is the actual statutory standard. As pointed out by the court in Caroldee Realty Corp. v. Board of Assessors, ${ }^{144}$ the traditional definition of market value is the price acceptable to the willing buyer and the willing seller. ${ }^{145}$ Commercial property is normally purchased for investment purposes, with a primary concern for the stream of income that actually will be available to the investor in the immediate future. ${ }^{146} \mathrm{~A}$ prudent investor would not buy property at a price which reflected fair rental value when actual income under the long-term lease is significantly less. This would amount to paying for income that he would never receive. The market value of such property must reflect the terms of the lease for its duration: ${ }^{147}$ to assess the taxpayer based on fair rental value is to disregard the economic realities of the situation. ${ }^{148}$

Yet in cases in which the owners are responsible for the diminished income of the property-where expenses or vacancies are higher than normal due to inefficient management-the owners should be taxed on the full earning capacity of the property, and thereby be made to assume their share of the tax burden. In such cases. the market value will reflect full earning capacity. Potential owners will be willing to pay more than the

141 See cases cited note 137 supra.

142 See $1 \mathrm{~J}$. Bonbright, The Valuation of Property 497-504 (1937); Note, The Valuation of Leaseholds for Ad Valorem Property Tax Purposes-The Reasonable Assessor Standard, 1968 WASH. U.L.Q. 136.

143 Text accompanying notes 99-103 supra.

14473 Misc. 2d 41, 340 N.Y.S.2d 774 (Sup. Ct. 1972).

145 Cases cited note 105 supra.

146 See Hollebaugh, supra note 107, at 58-60; Koeppel \& Kramer, supra note I27.

147 Cf. Koeppel \& Kramer, supra note 127, at 570.

148 An alternative solution entails separate taxation of "bonus" leases, with the tax to be levied directly on the lessee. See MASS. GEN. LAws ANn. ch. 59, $\S 11$ (1973). 
capitalized value of actual income because they believe that better management will decrease vacancies or cut expenses. ${ }^{149}$ The use of fair rental value in these circumstances is economically realistic as well as consistent with the policy of reducing the effect of managerial astuteness on property assessments. ${ }^{150}$

Once gross income is determined by using either fair or actual rental value, expenses must be subtracted to calculate net income for purposes of capitalization. Despite its importance in the valuation of income-producing property, there is little case law on the question of which expenses may be considered in calculating net income. The oldest cases, such as Somers $v$. Meriden, ${ }^{151}$ used full gross income and adjusted the capitalization rate upward for expenses. The court in Somers recognized the existence of certain norms regarding operating expenses for different types of income-producing property, and the possibility of adjusting the capitalization rate accordingly..$^{152}$

When fair rental value is used to calculate gross income, ${ }^{153}$ the courts have used estimates of expenses for average business years to calculate a stabilized net income. ${ }^{154}$ Expenses directly reflected in investors' calculations of market value-expenses that are expected to remain fairly constant in the future ${ }^{155}$ should be considered. Such expenses include vacancies, amortization costs, operating expenses (including maintenance and repair), and management fees. ${ }^{156}$ Property taxes should not be

${ }^{149}$ These cases must be distinguished from those in which the discrepancy between fair and actual rent is not attributable to inefficient management and therefore not reducible by a purchaser. Where the discrepancy is not under the control of the purchaser but results solely from the provisions of a long-term lease, fair value would overstate true market value and consequently would be an inappropriate basis for assessment. See text accompanying notes $152-57$ supra. On the other hand, a purchaser, unlike the original owner, justifiably could be taxed on fair rental value if the lease were "bad" when made. Once apprised of the existence of such a tax, a prospective purchaser could determine whether a long-term lease is "bad," and, as an investor, should adjust the purchase price to reflect the taxes that he knows will be imposed.

150 See New Brunswick v. Division of Tax Appeals, 39 N.J. 537, 189 A.2d 702 (1963): "[T] he valuations of properties for local taxation cannot vary with the managerial successes or failure of the owners. Adjacent properties of equal potential cannot be assessed differently because one proprietor was more or less astute than the other." Id. at $539,189 \mathrm{~A} .2 \mathrm{~d}$ at 706 .

151119 Conn. 5, 174 A.184 (1934).

152 For example, if operating expenses were normally $50 \%$ of gross income, and the capitalization rate for net income were $8 \%$, then the capitalization rate representing a proper return based on gross income would be $16 \%(.08 / .50)$.

${ }^{153}$ See notes $132-42$ supra \& accompanying text.

154 See cases cited note 134 supra.

${ }^{155}$ See New Brunswick v. Division of Tax Appeals, 39 N.J. 537, 189 A.2d 702 (1963); Hollebaugh, supra note 107, at 56-59; Smith, supra note 108.

${ }^{156}$ Hollebaugh, supra note 107 , at 57-58. The amortization expense, commonly re- 
deducted as an expense but should be included as part of the capitalization rate; it is unsound to deduct as an expense an amount that is affected by the end product of the calculation. ${ }^{157}$

The theory of fair rental income discussed previously ${ }^{158}$ suggests that estimated "fair" expenses rather than actual expenses should be deducted from gross income. Using such estimates provides desirable stability, and prevents tax avoidance in cases of inefficient management. A recent case ${ }^{159}$ indicated that it is often appropriate to give actual expenses prima facie validity as "fair" expenses, and to require the assessor to prove that the management is inefficient and actual expenses are above the norm. Where management is efficient, the market value should closely approximate the capitalized value of actual net income. Potential owners will have no reasonable expectation of increasing profits through better management and therefore will be unwilling to offer a price higher than that capitalized value. ${ }^{160}$

\section{(ii) Capitalization Rate}

The determination of the proper rate of capitalization is the most important, and the most difficult, step in valuation by the capitalization-of-income method. ${ }^{161}$ As noted earlier, ${ }^{162}$ the capitalization rate is a discount factor that converts a future stream of income into a present value; also, this figure represents the rate of return that an investor expects to receive from a particular investment. ${ }^{163}$ In determining the capitalization rate, the focus is upon the rate of return that investors in the particular kind of property actually require and receive. ${ }^{164}$

The capitalization rate is made up of many factors, and which factors are to be included will depend upon how net in-

ferred to as depreciation, can be included in the capitalization rate rather than being deducted from gross income as an expense.

157 KerTH, supra note 4, at 513.

${ }^{158}$ See notes 132-35, 143-49 supra \& accompanying text.

${ }^{159}$ Parkview Village Associates v. Borough of Collingswood, 62 N.J. 21, 297 A.2d 842 (1972).

${ }_{160}$ When sufficient evidence supports rejection of actual expenses, alternative means of estimating future expenses are available. The Urban Land Institute, for example, provides figures of normal operating expenses. See Ancel, supra note 126, at 258.

${ }^{161}$ BonBRIGHT, supra note 142 , at 259.

162 See text accompanying notes $127-29$ supra.

${ }^{163}$ See Hollebaugh, supra note 107, at 55; Smith, supra note 108, at 231.

${ }^{164}$ Burritt Mut. Sav. Bank v. Gity of New Britain, 146 Conn. 669, 154 A.2d 608 (1959); City of New Brunswick v. State Div. of Tax Appeals, 39 N.J. 537, 189 A.2d 702 (1963). 
come has been calculated. In each case the rate must include an interest factor-the monetary return on the invested capital. ${ }^{\mathbf{1 6 5}}$ If amortization of the investment (through depreciation) ${ }^{166}$ has not been deducted from gross income as an expense, then depreciation must be reflected in the capitalization rate. ${ }^{\mathbf{1 6 7}}$ Finally, the capitalization rate must be increased to take into account the effective rate of property tax that will be paid. ${ }^{168}$ The capitalization rate then reflects the return required by investors on income before property taxes, which is the net income to be capitalized. ${ }^{169}$ The three basic methods for determining the essential rate, prior to adjustment for expenses, are the summation method, the comparable-rate method, and the band-of-investment method. ${ }^{170}$

The summation method is an attempt to analyze the various characteristics of a particular investment and assign to each the rate of return required to compensate the investor. The primary factor is the safe rate-the rate of return which a fine deposit or treasury bill would produce. ${ }^{171}$ Other factors are added to the safe rate: a risk rate to compensate the investor for assuming the danger of loss of the invested capital, a liquidity rate to compensate for the potential loss in value if the investor is forced to sell on short notice, and a further rate to cover any management costs that have not been deducted as an expense. ${ }^{172}$ After these

165 See text accompanying note 171 infra.

${ }^{166}$ See note 156 supra \& accompanying text.

${ }^{167}$ The capitalization rate is increased only with respect to that part of net income which is attributable to the depreciable improvement. See City of New Brunswick v. State Div. of Tax Appeals, 39 N.J. 537, 549-50, 189 A.2d 702, 708-09 (1963).

168 See text accompanying note 157 supra.

${ }^{169}$ A short numerical example may be helpful:

$5 \%$ interest factor

$4 \%$ amortization (5\% depreciation factor multiplied by $80 \%$ of income from building)

$2 \%$ taxes ( $4 \%$ tax rate multiplied by $50 \%$ assessment ratio)

$11 \%$ capitalization rate

The $5 \%$ interest rate is a minimum rate, because it has not been adjusted for additional risks inherent in most real estate investments. See text accompanying note 172 infra. The amortization figure reflects a 20 -year life, with straight-line depreciation. The tax rate is adjusted because taxes actually to be collected are usually based on a percentage of fair market value.

${ }^{170}$ See Hollebaugh, supra note 127, at 60. See generally Ancel, supra note 126; Fisher, supra note 128.

${ }^{171}$ Fisher, supra note 128 , at 263 . This rate of return is called the safe rate because it is virtually guaranteed, and there is little or no risk that the invested capital will be lost.

${ }_{172} I d$. 
rates are added, additional rates for amortization and taxes are included when necessary. ${ }^{173}$

The comparable-rate method is analogous to the comparable-sales method. ${ }^{174}$ The procedure is to find investments similar to the subject property in terms of risk, liquidity, and management and tax costs, and then to determine the rate of return generated by these investments. The amount of the investment and the stream of income generated by the investment are the essential variables. As with the comparable-sales method, the comparable-rate method requires a sufficient number of comparable investments to permit a reliable comparison. ${ }^{175}$

The final method, the band-of-investment method, entails deriving a capitalization rate through the use of interest rates for equity and mortgage money. ${ }^{176}$ Prevailing rates for mortgage money are weighted according to how the property is financed. The equity rate is then added, also weighted according to the financing arrangement. ${ }^{177}$ The equity rate presumably would be determined by using either the summation method or the comparable-rate method, both of which reflect the rate of return investors require on their money, given the risks involved in the investment. ${ }^{178}$

\section{Proving a Common Ratio}

A second aspect of many appeals is proof of the common ratio within the taxing district. The property owner has shown his assessment to be invalid when he establishes that his property has a higher ratio of assessed value to market value than exists generally within the taxing district. ${ }^{179}$ When the common ratio is

${ }^{173}$ Notes 156-57 supra \& accompanying text.

${ }^{174}$ See text accompanying notes $111-16$ supra.

175 Fisher, supra note 128, at 264.

176 Ancel, supra note 126, at 261.

${ }^{177}$ The equity rate, therefore, represents the actual cost of capital as it is employed in the investment. Fisher, supra note 128, at 264. For example, if property were financed $80 \%$ with an $8 \%$ mortgage and the investor required a $15 \%$ return on his equity, the capitalization rate would be:

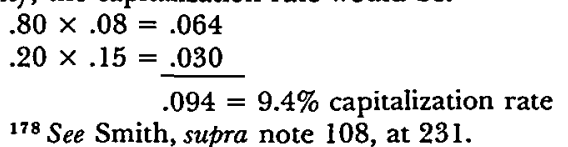

${ }^{179}$ Campbell Chain Co. v. County of Alameda, 12 Cal. App. 3d 248, 90 Cal. Rptr. 501 (1970); Hutensky v. Town of Avon, 163 Conn. 433, 311 A.2d 92 (1972); Feder v. City of Passaic, 105 N.J. Super. 157, 251 A.2d 457 (App. Div. 1969); Lunkenheimer Co. v. Board of Revision, 41 Ohio App. 2d 27, 322 N.E.2d 133 (1974); Deitch Co. v. 
set by statute at a specified percentage, the determination is straightforward: the market value previously determined ${ }^{180}$ is multiplied by the statutory percentage ${ }^{181}$ and compared with the value arrived at by the assessor. If the assessor's figure is higher, the taxpayer is entitled to have his assessment reduced to the lower figure. ${ }^{182}$ When no statutory ratio is designated, the taxpayer is entitled to be assessed at the average percentage actually applied within the district. ${ }^{183}$

Even when the percentage required by statute or announced by the assessor has been applied to the subject property, the challenging taxpayer may show that the common ratio actually applied throughout the taxing district is lower than the percentage required by statute or announced by the assessor. This procedure is important when the assessed value of the subject property reflects the proper fixed percentage of market value but the taxpayer believes that the assessor has not uniformly applied that percentage throughout the district. The proof of an actual common ratio is an extremely difficult task, and litigation of this type has been limited. ${ }^{184}$ The general procedure in proving such a common ratio is to perform sales-ratio studies, ${ }^{185}$ collecting evidence of the ratio of assessed value to market value for other real estate within the taxing district. ${ }^{186}$ In those juris-

Board of Property Assessment, 417 Pa. 213, 209 A.2d 397 (1965). See generally Sommer, supra note 78, at 483-85 (New York procedure).

The term "common ratio" implies that some degree of uniformity exists in the application of the specified percentage. Where assessment is so chaotic that no common ratio exists, the taxpayer may be permitted to establish the arithmetic mean of the percentages actually applied and to obtain a reduction of his own assessment to this level. See Continental Paper Co. v. Village of Ridgefield Park, 122 N.J. Super. 446, 300 A.2d 850 (App. Div. 1973), cert. denied, 63 N.J. 328, 307 A.2d 850 (1973). See generally Cheng, The Common Level of Assessment in Property Taxation, 23 NaT'L TAX J. 50, 51 (1970).

${ }^{180}$ See text accompanying notes $98-178$ supra.

181 See note 72 supra \& accompanying text.

182 See cases cited note 179 supra.

${ }^{183}$ See, e.g., Feder v. City of Passaic, 105 N.J. Super. 157, 251 A.2d 457 (App. Div. 1969); In re Brooks Bldg., 391 Pa. 94, 137 A.2d 273 (1958).

${ }_{184}$ Carr, supra note 14 , at 885-87. Ehrman, supra note 77, at 15. Hezel, supra note 69 , at $417-19$.

${ }^{185}$ Actual sales of other properties within the same taxing district are examined. The sale prices are regarded as evidence of fair market value, and the assessed value of each property is compared to the sale price to determine the assessment ratio. See Deitch Co. v. Board of Property Assessment, 417 Pa. 213, 218-19, 209 A.2d 397, 402 (1965); see Sommer, supra note 78, at 484.

${ }^{186}$ All jurisdictions maintain that a showing that selected parcels have been assessed at a lower ratio is insufficient to prove inequality; the taxpayer must establish that a lower ratio has been applied throughout the relevant geographical unit. Glidden Co. v. County of Alameda, 5 Cal. App. 3d 371, 85 Cal: Rptr. 88 (1970) (county); Feder v. City 
dictions where real estate comprises a single class entitled to uniform treatment, ${ }^{187}$ all real property should be available for use in the study. ${ }^{188}$ The problem is gathering sufficient data to ensure a representative sales-ratio study that will persuade a court or an appeals board. ${ }^{189}$

In order to encourage taxpayers to challenge assessment practices that produce illegally nonuniform ratios of assessed value to market value, several alternative methods of proof have been suggested. Some of the most successful challenges have been based on computer studies of assessments and sales which have generated data on existing common ratios. ${ }^{190}$ Computer studies of the required magnitude, however, are extremely expensive, and are therefore available only to taxpayers who can bear these costs. ${ }^{191}$

A less costly alternative was accepted in the New York case of In re Mid-Island Shopping Plaza, Inc. $v$. Podeyn. ${ }^{192}$ Tables of random numbers were used to select samples of real estate sales within the district. In each case, the assessed value was compared with the sale price ${ }^{193}$ to determine the ratio. ${ }^{194}$ The court stated that where a sufficient number of sales was tabulated, this method produced a reliable and representative sample of the actual ratios applied to properties within the district. ${ }^{195}$

Another method of proving a common ratio different from

of Passaic, 105 N.J. Super. 157, 251 A.2d 457 (App. Div. 1969) (city); Pollack v. Reed, 47 App. Div. 2d 842, 366 N.Y.S.2d 31 (1975); Lunkenheimer Co. v. Board of Revision, 41 Ohio App. 2d 27, 322 N.E.2d 133 (1974) (state); Note, supra note 14, at 1382.

${ }^{187}$ See cases cited note 34 supra.

${ }^{188}$ Deitch Co. v. Board of Property Assessment, 417 Pa. 213, 223, 209 A.2d 397, 402-03 (1965).

${ }^{189} I d$.

${ }^{190}$ See cases cited note 56 supra.

191 If successful methods of attack require the use of expensive techniques, regressive effects on the uniformity of the system may result. See Rosett, Inequity in the Real Property Tax of New York State and the Aggravating Effects of Litigation, 23 NAT'L TAX J. 66 (1970).

19225 Misc. 2d 972, 204 N.Y.S.2d 11 (1960), aff'd, 14 App. Div. 2d 571, 218 N.Y.S.2d 249, aff'd, 10 N.Y.2d 966, 180 N.E.2d 63, 224 N.Y.S.2d 283 (1961).

${ }^{193}$ The sale prices were determined from the transfer tax (documentary) stamps attached to the deeds. Id. at 976,204 N.Y.S.2d at 15 . The sale prices also could have been obtained from the assessor, who is likely to keep records of such information, or from the state board of equalization, which often performs its own sales-ratio studies.

$194 \mathrm{It}$ is important in this type of case to require the assessor to reveal the assessments of those properties that are randomly selected for the study. See notes 81-84 supra \& accompanying text.

${ }^{195}$ This method assumes that sale prices reflect the fair market value of the various properties. Each sale must therefore be examined to verify that it was conducted at arm's length and between parties of equal bargaining power. 
the percentage required by law relies on sales-ratio studies executed by the state board of equalization. ${ }^{196}$ In jurisdictions which do not set a statewide fixed percentage, it is necessary to equalize state tax rates among the various counties to ensure that the state constitutional requirement of uniformity is met. In the course of performing its equalization function, the state board normally conducts its own sales-ratio studies for each taxing district, and then adjusts the ratio for each district to create uniformity. Even where a statewide percentage is set by law, studies are often done to monitor the success of assessors in each district in maintaining the assessment system at the statewide fixed percentage. ${ }^{197}$ It would be reasonable, as many legislatures have recognized, ${ }^{198}$ to require that the state board publish its sales-ratio data and to accord these studies probative value in taxpayer appeals as evidence of actual common ratios. In California, for example, the local appeals board is now required to accept as the actual ratio the lowest of: the ratio announced by the assessor, 115 percent of the ratio determined by the state board, and the ratio proved by the taxpayer. ${ }^{199}$ In view of the problems involved in proving actual ratios, it seems both fair and desirable to make additional evidence for proof of inequality available to the taxpayer. ${ }^{200}$

\section{B. Judicial Review}

After exhausting the available administrative remedies, the taxpayer may seek judicial review of his assessment. ${ }^{201}$ Statutes in most jurisdictions provide for such an appeal, ${ }^{202}$ but significant differences exist in the scope of review that the courts will

${ }^{196}$ See Cal. Rev. \& TAx Code $§ \S 1815,1817-19$ (West 1970), as amended, (Supp. 1976); Mass. Gen. Laws ANn. ch. 58, § 10-10A (1973); N.Y. Real Prop. Tax Law $\S \S 1200-02$ (McKinney 1972); Ohio Rev. Code AnN. \$ 5715.07 (Page 1973).

${ }^{197}$ See Carr, supra note 14 , at 887.

${ }^{198}$ See, e.g., Cal. Rev. \& TaX Code $\S \$ 1818-19$ (West 1970), as amended, (Supp. 1976); N.Y. Real Prop. TaX Law $\$ 720$ (McKinney 1972).

${ }^{199}$ Cal. Rev. \& TAX Code $\S 1605$ (West 1970); Ehrman, supra note 77, at 16. But see Glidden Co. v. County of Alameda, 5 Cal. App. 3d 371, 85 Cal. Rptr. 88 (1970) (taxpayer not entitled to assessment in accordance with state board ratio absent a showing that value determined by state board was equal to fair market value).

${ }^{200}$ See Fusfeld \& Kowalski, Reforming the Michigan Property Tax, 49 Мrсн. S.B.J. 13, 18 (July 1970).

201 See, e.g., Conn. Gen. Stat. Ann. \$§ 12-111, -118 (1972); Mass. Gen. Laws Ann. ch. 58A, § 13 (Supp. 1975); Ohro Rev. Code ANN. \$§ 5717.01, .04 (Page 1973). The exhaustion requirement has been strictly applied. See, e.g., Grossman v. Board of Trustees, 44 App. Div. 2d 259, 354 N.Y.S.2d 188 (1974).

${ }^{202}$ See, e.g., Conn. Gen. Stat. Ann. \$ 12-118 (1972); Mass. Gen. Laws Ann. ch. 58A, 13 (Supp. 1975); N.Y. Real Prop. TaX Law $\S$ 700-26 (McKinney 1972); OHio Rev. Code AnN. § 5717.04 (Page 1973). 
undertake. Some states limit review to the procedures and methods employed by the local board and the assessor and consider only whether the procedures were illegal, fraudulent, or arbitrary, ${ }^{203}$ or whether the valuation was illegal, arbitrary, or intentionally discriminatory. ${ }^{204}$ When the assessor and administrative agencies have employed recognized methods, the property is deemed to have been properly assessed. ${ }^{205}$ This narrow scope of judicial review, although consistent with the general theory of administrative expertise ${ }^{206}$ is inappropriate in the area of real estate assessments. There is little indication that local appeals boards have the technical expertise in commercial real estate appraisal that would justify judicial deference. ${ }^{207}$ Few states prescribe any qualifications for persons sitting on these local boards, ${ }^{208}$ and there is no indication that their members are more qualified than trial judges to render proper decisions. Moreover, limiting relief to cases involving improper methods would be inconsistent with the constitutional and statutory requirements of proportional taxation; those requirements are more result- than means-oriented, and relief should not be so limited. ${ }^{209}$ Given the difficulty of the subject matter, as well as the heavy burden of proof on the taxpayer, a broader scope of judicial review should be available. ${ }^{210}$

${ }^{203}$ See, e.g., Weil v. Supervisor of Assessments, 266 Md. 238, 292 A.2d 68 (Ct. App. 1972) (courts cannot be required to act as a board of review for property assessments). See also Hellerstein, supra note 14, at 332.

${ }^{204}$ Cal. Rev. \& Tax CODE $\$ 1611$ (West Supp. 1976). This includes an "abuse of discretion" standard under which mere errors of judgment are insufficient to warrant reversal. See, e.g., County of Los Angeles v. Tax Appeal Bd., 267 Cal. App. 2d 830, 73 Cal. Rptr. 469 (1968); Ehrman, supra note 77, at 21 . Where a statewide appeals board has been created, the standard of judicial review is usually whether the decision of that board is supported by substantial, credible evidence on the record as a whole. See, e.g., Parkview Village Associates v. Borough of Collingswood, 62 N.J. 21, 297 A.2d 842 (1972).

${ }^{205}$ Weil v. Supervisor of Assessments, $266 \mathrm{Md}$. 238, 292 A.2d 68 (1972).

${ }^{206}$ See, e.g., Universal Camera Corp. v. NLRB, 340 U.S. 474 (1951); Gray v. Powell, 314 U.S. 402 (1941).

${ }^{207}$ See Carr, supra note 14, at 883-84. The special statewide appeals boards for the review of assessments, on the other hand, have specially qualified members, who receive judicial recognition of their expertise. See, e.g., City of East Orange v. Township of Livingston, 103 N.J. Super: 109, 113-14, 246 A.2d 722, 725 (App. Div. 1968).

${ }^{208}$ See, e.g., N.J. STAT. ANN. \& 54:3-2 (Supp. 1975) (requiring citizenship in county comprising the taxing district).

${ }^{209}$ Contra, Shoppers' World, Inc. v. Board of Assessors, 348 Mass. 366, 203 N.E. 2d 811 (1965).

${ }_{210}$ The arguments for broader judicial review in a somewhat different context are set out in Schwartz, Legal Restriction of Competition in the Regulated Industries: An Abdication of Judicial Responsibility, 67 HARv. L. REv. 436, $471-75$ (1954). 
Many states have adopted this view and permit de novo review of assessments. Thus, the reviewing court makes its own findings of market value ${ }^{211}$ and common ratio. ${ }^{212}$ Overvaluation by the lower agencies is sufficient to justify redress. This broad scope of review permits courts to grant relief without attributing to the assessor or the local boards the mala fides implicit when relief is granted under the narrower scope of review. ${ }^{213}$ When the appeals board's expertise is questionable and the remedies obtainable from a reviewing court are adequate, ${ }^{214}$ the additional "bite at the apple" provided by de novo review is likely to promote equality by reaching and remedying errors that went uncorrected by the lower agencies and would not be corrected under the narrower scope of review.

The adoption of de novo review also introduces some difficulties. In substantively reviewing real estate assessments, the courts are performing a function that generally is outside the range of judicial expertise, ${ }^{215}$ and therefore expert testimony almost always will be required in establishing market value and in challenging the common ratio. Thus, effective appeals may be available only to taxpayers with the resources to obtain expert witnesses. Because the appeal procedure is a necessary tool for attaining uniformity and equality in a real estate tax system, ${ }^{216}$ it is important that appeals be widely available. ${ }^{217}$ Massachusetts has recently instituted an alternative, informal procedure for handling taxpayer appeals. ${ }^{218}$ Under this procedure, the Appellate Tax Board may eliminate most formal rules of pleading,

${ }^{211}$ See, e.g., Dickau v. Town of Glastonbury, 156 Conn. 437, 242 A.2d 777 (1968);

McKnight Shopping Center, Inc. v. Board of Property Assessment, $417 \mathrm{~Pa} .234,209$ A.2d 389 (1965).

212 See, e.g., Rek Inv, Co. v. City of Newark, 80 N.J. Super. 552, 194 A.2d 368 (App. Div. 1963).

${ }^{213}$ Hellerstein, supra note 14, at 335.

214 The relief that should be granted is reduction of tax liability to the level at which it would have been set if the common ratio had been applied uniformly throughout the taxing district. See text accompanying notes 219-24 infra.

${ }^{215}$ See Hellerstein, supra note 14 , at 336.

216 See authorities cited note 14 supra.

${ }^{217}$ Recent empirical studies indicate that the cost of court appeals has introduced inequity into property tax assessment systems. Because the incentive to appeal is strongest when the amount of the disputed tax is large, it is likely that only the comparatively wealthy taxpayers will appeal. See Rosett, supra note 191, at 66.

${ }^{218}$ Mass. Gen. Laws ANn. ch. 58, § 7A (Supp. 1975). This informal procedure should expedite appeals and reduce substantially the expenses of litigation. See Leen $\mathbf{v}$. Board of Assessors, 345 Mass. 494, 188 N.E.2d 460 (1963). The availability of such procedures is limited, however, to disputes involving small parcels, and may require waiver of rights to judicial review in certain cases. 
practice, and evidence, as well as some or all fees and costs. The availability of this procedure should eliminate some of the inequalities inherent in litigation under the traditional system, and should supplement the advances toward uniformity made currently through broad judicial review.

\section{Remedies}

Given a sufficiently broad scope of review, the courts have held universally that when the taxpayer is able to prove overassessment, he has the right to have his assessment reduced to the percentage of market value at which other property is assessed within the district. ${ }^{219}$ This is true even where the state has a system of full value assessment and the reduction would be a departure from the requirements of the state statute. ${ }^{\mathbf{2 2 0}}$

One result of the widespread availability of relief through the reduction of the taxpayer's own assessment has been the elimination of the mandamus remedy obtained in early cases such as Switz ${ }^{221}$ and Bettigole. ${ }^{222}$ Because the reduction of the assessment to the common level is an adequate remedy, taxpayers have been limited to that remedy, and the courts generally have refrained from intervening further in the system. ${ }^{223}$ This trend also has eliminated the need for additional legislative changes in reaction to mandamus orders. ${ }^{224}$

\section{Conclusion}

In the past fifteen to twenty years the states have made significant advances toward improving the efficiency and uniformity of their real estate tax systems. Probably the strongest objective evidence that greater uniformity has been achieved is that between 1961 and 1971 thirty-eight states reduced the dispersion of common ratios within their taxing districts. ${ }^{225}$

${ }^{219}$ See cases cited notes 25, 179 supra; Hutensky v. Town of Avon, 163 Conn. 433, 311 A.2d 92 (1972).

${ }_{220}$ See, e.g., Bettigole v. Assessors of Springfield, 343 Mass. 223, 178 N.E.2d 10 (1961); In re Kents 2124 Atlantic Ave., Inc., 34 N.J. 21, 166 A.2d 763 (1961).

221 Switz v. Township of Middletown, 23 N.J. 58, 130 A.2d 15 (1957).

222 Bettigole v. Assessors of Springfield, 343 Mass..223, 178 N.E.2d 10 (1961).

${ }^{223}$ Sears Roebuck Co. v. Somerville, __ Mass. __, 298 N.E.2d 693 (1973); State ex rel. Corron v. Wisner, 23 Ohio App. 2d 1, 260 N.E.2d 608 (1970). But see Hellerstein v. Assessor, 37 N.Y.2d 1, 332 N.E.2d 279, 371 N.Y.S.2d 388 (1975) (ordering prospective full value assessment).

${ }^{224}$ But see N.Y. Times, Mar. 10, 1976, at 30, col. 1 (discussing a bill pending in the New York State Assembly which would legalize fractional assessment); note 67 supra.

${ }^{225}$ See Welch, supra note 2, at 33. 
The improvement largely has been due to the authorization of fractional assessment by the state legislatures. At the beginning of the period under review, it was clear that the assessors had established systems in which conformity to constititutional and statutory valuation standards was the exception rather than the rule. After the courts invalidated these systems as contrary to legal requirements, the legislatures effectively improved them by conforming the legal standards to the existing system. This change increased equality by enabling taxpayers to detect overassessment and thereby challenge and remedy such inequality. Significantly, this improvement was made with no loss of simplicity in the system nor any additional burden on taxpayers who sought to appeal their assessments.

The change to fractional assessment was often accompanied by provisions making new information available to taxpayers. Information such as local assessments and sales-ratio studies is crucial; not only does it apprise property owners of existing conditions in the taxing district, thereby exposing any overassessment, but it also encourages taxpayer appeals by facilitating proof that overassessment exists. This is expecially true about sales-ratio studies, because where they are accepted as probative evidence of a common ratio the taxpayer's chances of success are significantly increased. As the sales-ratio studies become more sophisticated and accurate, more states perhaps will accept such data for purposes of appeal, thereby increasing the ability of taxpayers successfully to challenge overassessments.

Also accompanying the change to fractional assessment was the increased availability of administrative and judicial review. One significant change was the creation of statewide administrative appeals agencies with plenary review over the decisions of local appeals boards. Staffed with properly qualified members, such boards eventually will be given the deference on appeal normally accorded to administrative agencies. The increased use of broad judicial review, which led the courts away from a review of methods of assessment and towards an examination of results, was a further improvement. Broad judicial review significantly improves equalty, by ensuring that a taxpayer who is overassessed may obtain relief whatever the reason for overassessment. The end product is a more equal system, in which taxpayers have a right to be taxed, as well as assessed, uniformly. 